\title{
Constructions of migrant rights in Canada: Is subnational citizenship possible?
}

Rupaleem Bhuyan and Tracy Smith-Carrier

\author{
Version Accepted Manuscript \\ Citation Bhuyan, R., \& Smith-Carrier, T. (2012). Constructions of migrant rights \\ (published version) in Canada: Is subnational citizenship possible? Citizenship Studies, 16(2), \\ 203-221. http://dx.doi.org/10.1080/13621025.2012.667613 \\ Publisher's Statement This is an Author's Original Manuscript of an article submitted for \\ consideration in Citizenship Studies. Copyright Taylor \& Francis. \\ Citizenship Studies is available online at \\ http:/ /dx.doi.org/10.1080/13621025.2012.667613
}

\section{How to cite TSpace items}

Always cite the published version, so the author(s) will receive recognition through services that track citation counts, e.g. Scopus. If you need to cite the page number of the TSpace version (original manuscript or accepted manuscript) because you cannot access the published version, then cite the TSpace version in addition to the published version using the permanent URI (handle) found on the record page. 
"This is an Author's Original Manuscript of an article submitted for consideration in Citizenship Studies. Copyright Taylor \& Francis. Citizenship Studies is available online at http://dx.doi.org/10.1080/13621025.2012.667613

\title{
RESEARCH ARTICLE
}

\section{Constructions of migrant rights in Canada:}

\section{Is subnational citizenship possible?}

\author{
R. Bhuyan, $\mathrm{PhD}^{1}$ \\ T. Smith-Carrier, $\mathrm{PhD}$ (Cand) \\ Factor-Inwentash Faculty of Social Work \\ University of Toronto, Toronto, Ontario, Canada
}

${ }^{1}$ Correspondence Address: Rupaleem Bhuyan, Factor-Inwentash Faculty of Social Work, University of Toronto. Email: r.bhuyan@utoronto.ca. 


\begin{abstract}
Devolutionary trends in immigration and social welfare policy have enabled different levels of government to define membership and confer rights to people residing within the political boundary of a province or municipality in ways that may contradict federal legal status. Drawing upon theories of postnational and deterritorialized citizenship, we examined the legal construction of social rights within federal, provincial and municipal law in Toronto, Ontario. The study of these different policy arenas focuses on rights related to education, access to safety and police protection, and income assistance. Our analysis suggests that the interplay of intra-governmental laws produces an uneven terrain of social rights for people with precarious status. We argue that while provincial and municipal governments may rhetorically seek to advance the social rights of all people living within their territorial boundaries, program and funding guidelines ensure that national practices of market citizenship and the policing of non-citizen subjects are reproduced at local levels.
\end{abstract}

Keywords: $\quad$ Rights, Non-Citizen, Legal Status, Citizenship, Welfare State 
Scholarship on the social rights of citizenship suggests the nation-state is no longer the presumed territory within which rights and social membership are constructed. Through global migrations, communication technologies, and the growing influence of supra-national human rights institutions, populations across national contexts have "challenged the notion of citizenship tied to the terrain and imagination of a nation-state' (Ong 2006, p. 499). Conceptualizations of neoliberal citizenship have also shifted the boundaries of social membership such that long-term residence within a nation is no longer connected to social rights within the nation (Fix and Tumlin 1997). Denationalized notions of allegiance and belonging (Sassen 2003) have in part been usurped by more market-driven transnational mobility and a reassembling of rights previously associated with membership, territory and identity (Ong 1999). Within this stream of theorizing citizenship, we consider in what ways devolutionary trends in social welfare and immigration policy contribute to this disarticulation, while enabling regional and local governments to determine membership and allocate public resources to guarantee social rights for non-citizen subjects. Our analysis falls within what Varsanyi (2006) terms 'post-postnational' scholarship, which she describes as scholarship that seeks to acknowledge 'the contradictions of nation-state citizenship' (p. 230), while maintaining that nation-state citizenship and federal authority to define legal status continues to significantly shape the lives of migrants.

A number of different terms, from pejorative to more accommodating, are used to refer to residents who lack legal status—alien, non-status, sans papiers, illegal and undocumented. Within Canada, the visibility of non-status migrants remains contested as little empirical evidence is available (either from government or nongovernment sources) to calculate the proportion of people residing in Canada without legal status. Nevertheless, shifts in Canadian immigration policy have produced new and longer episodes of temporary and precarious status 
through more restrictive refugee determination processes and marked growth in temporary foreign worker programs (Crépeau and Nakache 2007). In 2009, nearly 1 million temporary residents were accounted for by Citizenship and Immigration Canada (Citizenship and Immigration Canada 2009). Considering the total population in Canada is estimated at 34 million, up to 1 in 34 people living in Canada have a form of precarious migratory status within the Canadian immigration system. This calculation does not account for the unknown number of non-status people residing in Canada.

In an effort to disrupt the perceived binary between status and non-status, Goldring, Berinstein and Bernhard (2010) have suggested the term 'precarious immigration status' or 'precarious status' more accurately captures the fluidity within the production of illegality and exclusion in Canada's immigration regime. Precarious status is associated with the absence of features commonly attached to permanent residence and citizenship in Canada including:

1) Work authorization;

2) The right to remain permanently in the country (residence permit);

3) Not depending on a third party for one's right to be in Canada (such as a sponsoring spouse or employer); and

4) Social citizenship rights available to permanent residents (e.g. public education and public health coverage)" (Goldring et al. 2010, p. 214).

The focus on precarious status highlights that individuals fall within a shifting continuum of legal rights that is marked by both the potential change in one's status and one's deportability. For example, an individual may have authorized status for a temporary period on a work permit or study visa, which after expiration creates a new situation of 'illegality' (sic); which may or 
may not lead to the pursuit of legal status yet again (e.g. through another temporary work permit or study visa or avenues of permanent residency including refugee claims).

It is no accident that research on precarious status has emerged in the context of Toronto, Ontario, a city that exemplifies Saskia Sassen's (2001) notion of a global city which has participated in shifting the infrastructure of global capital and transnational migration. More than half of Toronto's population is foreign-born, while the majority of Canada's foreign-born population $(88.8 \%)$, who now make up approximately 1 in 5 people living in Canada, reside in the province of Ontario (Statistics Canada 2009). Using Toronto as a case example, we analyze public policy at various levels of government to explore in what ways sub-national territoriesthe city, the province - are defining social membership in compliance or contradiction with the federal government.

In this paper, we contextualize our analysis of social rights within a post-Keynesian welfare state characterized by devolution and neoliberal restructuring. We then look at theories of post-national citizenship which explore the various assemblages of rights and social membership that have accompanied global flows of people and capital; in addition to constraints placed on rights and membership under the guise of market-based citizenship, state security and sovereignty. Finally, we provide four examples to illustrate how social rights are constructed across federal, provincial and municipal law with a focus on: 1) definitions of membership that signify precarious status, 2) rhetorical assurances and structural limits for access to public education, 3) restrictions on freedom from harassment and discrimination, and 4) assessments of worthiness for social assistance and citizenship. Through each example, we interrogate how ideologies of market citizenship and securitization mitigate the extension of rights to migrants with precarious status who are deemed unworthy of social rights by different levels of 
government. Our analysis suggests that the interplay of intra-governmental laws produces an uneven terrain of social rights. We argue that while provincial and municipal governments may rhetorically seek to advance the social rights of all people living within their territorial boundaries, program and funding guidelines ensure that national practices of market citizenship and the surveillance and policing of non-citizen subjects are reproduced at local levels.

\section{Literature review and theoretical framework}

\section{Devolution and the rise of market citizenship in Canada}

Devolutionary trends in social welfare policy in Canada have accompanied the retrenchment of the welfare state as responsibilities for social welfare and entitlement programs once at the national level of governance devolved to local levels, without the funding structures to support them (Graham et al. 2009). Canadian federalism historically included the cost sharing of health and human services between the federal and provincial governments, under federal oversight. Decentralist aspirations coupled with fiscal pressures concretized in 1995 with the Canada Health and Social Transfer, a block grant program that both substantially cut federal spending on social welfare programs and literally transferred funds for social and health programs for provinces to administer (Doherty et al. 1998). Devolutionary trends in Canada occurred in tandem with neoliberal restructuring at the federal level (Morris 1997). Some provincial governments, according to McBride and Mcnutt (2007), also employed their increased discretionary powers over public programs to adopt neoliberal reforms that resembled welfare reform in the United States as was the case in both Ontario and British Colombia.

Scholarship on immigration federalism has highlighted the devolution of immigration enforcement to local authorities (Spiro 2001, Decker et al. 2008, Varsanyi 2008) along with increased participation of regional and local governments in managing the integration and 
settlement of immigrants (Cameron and Simeon 2002, Graham et al. 2009). In Canada, immigration control policy (keeping out unwanted immigrants) is constitutionally deemed a 'concurrent power' ostensibly shared by federal and provincial governments. In practice, the federal government has retained authority over immigration control while immigrant integration policy (managing the recruitment, settlement and integration of desired immigrants) has been significantly downloaded to provincial and municipal governments (Boushey and Luedtke 2006). Ong (1999) argues that market citizenship and the logic of economic reason permeates the neoliberal state espousing clear gendered (Schild 2000) and racial assumptions (Dobrowolsky 2008). Increasingly, the reinvented welfare state envisaged by Hewitt (1996) has achieved ascendancy as a state designed to:

...(P)romote participation in social institutions and particularly, the labour market...to build the capacity of individuals - their capacity to learn, to earn, and to take responsibility, and to contribute to relationships with others, within families and the wider community (p. 260, emphasis added).

Shaping law and policy, the principal focus on duties and obligations to constitute the good citizen have advanced the autonomous, responsible choice-making citizen who supports the state best by becoming 'entrepreneurs of the self' (Ong 2003, p. 9). The idealized neoliberal or market citizen is the flexible homo economicus, elevated on the basis of self-sufficiency and entrepreneurial fortitude. The moulding of subjects, into greater approximations of this idealized citizen, incites a variety of knowledges (Foucault 1980) used to shape the conduct of subjects, maximizing certain capacities whilst minimizing particular risks. Unproductive subjects are obliged, in adherence to norms of self reliance and autonomy, to become good, contributing citizens (Ong 2003). The continuum of deservedness, enmeshed in gender and racial ascriptions 
of the neoliberal state, continually (re)defines the line between those with 'status' from those without.

\section{Dissassembling rights from citizenship and the nation}

Globalization and increased volume and diversity of migratory flows of people and capital have contributed an eroding Keynesian welfare state; disrupting Marshall's seminal conception of social, political and civil rights as an achievement of liberal democracy (Marshall 1992). Marshall's analysis of social citizenship signalled the state's responsibility to assure a basic minimum standard of life with the state intervening in times when one's labour was not, or no longer needed (i.e. old age security, welfare or disability benefits). Marshall's assertion that the rights of citizenship be limited to individuals who fulfilled their duties and responsibilities (i.e. through education, military service, waged employment) attests that market driven values are long-lasting features of citizenship. Munger further argues that '[full] social citizenship is a benefit derived from fulfillment of a social contract and not from legal status as a citizen' (2003, p. 674). Analyzing the contractual approach to citizenship dispels the assumption that all citizens have equal access to entitlement programs. Rather, social rights are only available to citizens who can successfully demonstrate worthiness to be part of society along ideological lines (i.e. productive worker, self-reliant individual, heteronormative in family formation)(Munger 2003).

Drawing upon neoliberal logic, states have jettisoned programs with 'universal' entitlements for citizens and long-term residents (if programs could ever have been considered universal in scope), while welfare provisions have increasingly been demarcated within narrow 'eligibility' requirements towards socially and spatially targeted policies adopted to identify a 'problem group of non-normative citizens' (Cowen 2005, p. 337). While there is extensive debate on the future role of a Keynesian welfare state amidst pressures of globalization and 
neoliberal reforms (Epsing-Andersen 1996, Mishra 1999, Glatzer and Rueschemeyer 2005, Midgley 2007), the very notion of social citizenship has always failed to account for the social and economic rights of non-citizens residing and often times working alongside their citizen neighbours.

\section{Postnational and denationalized citizenship}

Theories of citizenship, as noted by Bosniak (2006), typically do not account for undocumented or 'irregular migrants', rendering invisible the growing numbers of people who reside within a particular nation-state as non-citizens and are both formerly and in practice excluded from democratic liberal society. Towards assessing the shifts produced through globalization, theories of postnational or denationalized citizenship have focused on how citizenship is located 'beyond the boundaries of the nation-state' (Bosniak 2000, p. 450). To capture different dimensions of citizenship in practice, Bosniak (2000) suggests looking at citizenship - as a) a legal status, b) a system of rights, c) a form of political activity and/or d) a form of identity and solidarity. Within each of these realms, Bosniak argues that citizenship remains a signal of material and political consequence. Yet the boundaries of participation and thus inclusion for each of these realms, has the potential to produce different forms of membership despite one's recognition within formal juridical citizenship.

Ong (1999) suggests that the mobility of capital across national borders facilitates the disarticulation of dimensions of citizenship, rights, entitlements, a state, a territory towards 'global assemblages' - meaning the extension of rights to non-citizens whose transnational mobility is fuelled by their flexibility, wealth and talent. On the other hand, Calavita's (2005) scholarship illustrates how states' seek to promote fluid labour in response to market needs, while taking steps to exclude migrant workers from full participation in the social contract of the 
host-state. The post 9/11 political climate, $\underline{\text { Chan (2005) }}$ argues, has reinforced the molding of subjects along the binary of good/bad immigrants. As such, the purview of regional and local governments to recognize subjects capable of fulfilling neoliberal values versus those perceived to be 'market failures', is further mitigated by the nation-state's perception of 'foreign' subjects who intrinsically pose a threat to national sovereignty.

\section{Rights in conflict with national security}

A final dimension of our analysis addresses the tension between upholding rights envisioned in either universal human rights discourses or social citizenship, with the notion of 'foreigners' as perceived threats to national sovereignty. Canada, more so than the United States, has incorporated international human rights discourses into federal and provincial policies, while also creating commissions at the federal and provincial level charged with investigating complaints regarding human rights violations. However the distinction between human rights as representing international conventions versus domestic or national policy is less clear in Canada. Nevertheless, while individuals have several mechanisms to make human rights appeals through federal and provincial legislation and institutions, Bruce Porter from the Social Rights Advocacy Centre in Toronto (2005) contends that Canadian jurisprudence continues to question the justiciability (or limits within which an issue can be addressed by the law) of social and economic rights as question of the constitutional status of vulnerable and disadvantaged groups within Canada.

Within liberal democratic states the protection of individual rights increasingly comes in conflict with perceived threats to national security (Schmidtke 2008). Drawing from Benhabib's (2004) work, Schmidtke argues that 'to protect the democratic sovereign, rights to national self- 
determination are given priority at the expense of universal human rights' $(2008$, p. 6$)$. On the 'Other' side of the venerated homo economicus is the constructed threat to 'national security' which requires surveillance and securitization. The resulting link between precarious immigration status and criminality is now well documented in the literature (Nyers 2005, Dobrowolsky 2008, Dhamoon and Abu-Laban 2009). Politicians and the media have fed into a policy frame which stigmatizes those with precarious status in the parlance of illegality, unlawfulness, threats to national security, those perceived to be going through the back door (Anonymous 2006), and queue jumpers (although for those without financial status or specific skills sets, there is no queue (Koehl 2007, p. 59) or unguarded route to citizenship). The emergent emphasis on securitization in response to fears of leaky borders (Gilbert 2007) overlooking surreptitious passage of 'illegal' migrants in Fortress North America (Shantz 2005), present key expressions of the constructed need for surveillance in the era of governmentality.

In the context of neoliberal and devolutionary trends which have produced denationalized or postnational assemblages of citizenship, scholars have asked, where can citizenship take place? Varsanyi's (2006) analysis of urban and local citizenship in the United States explores how local policies have extended membership to undocumented migrants who are living in communities as 'neighbours, family members, customers, parents to school children, and in many other ways, regular participants in the life of their communities' (p. 240). The growth of local immigration laws, by cities and state governments in the United States is in part a response to the stalemate of immigration reform at the federal level. Varsanyi suggests, 'these local polices represent a de facto consent for the formal membership of these individuals... In effect they are being (partially) recognized as local or sub-national citizens under jus domicile standards, which base membership upon residence' (2006, p. 240, emphasis in original). In her 
critique of Soysal (1994), Varsanyi contends that "local "citizenship" policies are paradoxically made possible by the legal framework of the nation-state, as opposed to, for instance, being legitimated by the international human rights regime' (2006, p. 244). This line of inquiry offers a compelling direction for our policy analysis in Canada. Varsanyi’s (2008) analysis of 'grassroots' immigration laws in the United States, however, may be specific to American federalism. While municipalities in Canada are less likely to pass ordinances that challenge federal authority, local and provincial governments are involved in the implementation of federal policy in part due to devolutionary trends and the extensive reach of national security efforts.

\section{Methodology}

This paper grew out of a larger research project to explore the discourses of citizenship and illegality that are produced in public policy and service delivery to immigrants with precarious status. In this paper, we analyze public policy documents at the federal, provincial and municipal level to illuminate the discourses surrounding the expression of social rights for immigrants with precarious status in Toronto, Ontario. The policy texts used in this study included a range of social welfare, health and immigration policies at the federal, provincial and municipal level. Policy documents were identified through online searches, key informant interviews that were part of the larger study on service delivery to migrants in Toronto, and through cross-referencing of policy documents previously identified. See Table 1 for a complete list of the policy documents and issuing level of government.

\section{[Insert Table 1 here]}

\section{Table 1: Policy Documents by Level of Government}

Our research questions explored: (1) What social rights are constructed for immigrants with precarious status vis-à-vis Canadian citizens or permanent residents?; (2) What are the 
dominant discourses and implicit meanings of the discourses framing the social rights of these populations?; (3) How do discourses from one policy arena correspond to or differentiate from discourses in other policy arenas (e.g. how are federal discourses constructing social rights taken up in provincial or municipal policy documents)?

Our method of analysis drew from post-structural theories of language as a social action. We follow Fonow and Cook's (2005) frame for intertextual analysis as "the study of how symbolic codes in one text are related to those in another which allows the researcher to compare and contrast similar themes within or among different genres of [text]" (p. 2221). Gadamer, (1979) drawing from Bakhtin's work on speech acts, theorizes how language carries a historic legacy such that words are populated with others' interests. Bakhtin (1981) referred to this phenomenon as the evaluative accent of words. Given that language is a social action, the words we use to represent the world around us also reflect our intentions (or rather our ability to get what we want). In our analysis of public policy, we examine the evaluative accent of words to examine the ideological investments that are produced through policy texts.

Our use of a multimodal approach seeks to highlight particularly highly loaded lexical choices (use of specific words or terms) in written text (Caldas-Coulthard 2003) towards illustrating how language contributes to the representation of ideology (Van Dijk 1993, Yanow 2000). The analysis process included an iterative series of coding the corpus of data in relation to our analytic frames related to market citizenship, governmentality and constructions of precarious status. Our analysis revealed a number of areas pertaining to how social rights and social membership are constructed for citizens vis-à-vis those lacking citizenship, as well as examples of how federal efforts to regulate populations deemed risky to the nation impact the provincial and municipal allocation of social rights. Figure 1 provides a visual depiction of the 
social rights domains and analytic frames examined in the study. We present our analysis juxtaposing homo economicus — used to define the good, desirable citizen — with constructions of precarious legal status as criminal and threatening to national security. (Insert Figure 1 Here)

Figure 1- Social rights domains and analytic frames

\section{Analysis}

\section{Constructions of precarious status in federal, provincial and municipal law}

The Government of Canada signifies precarious status in their definition of a 'foreign national'. According to the Immigration and Refugee Protection Act (IRPA), 'foreign national means a person who is not a Canadian citizen or a permanent resident and includes a stateless person' (Government of Canada 2001, p. 2). Merriam-Webster definition of 'foreign' includes a person who is "alien in character: not connected or pertinent..." (Merriam-Webster 2010, emphasis added). DeGenova (2005) further contends that since 9/11, foreign marks those who are encompassed within the production of 'illegality' and thus are deportable.

Being identified as foreign is to be 'not connected or pertinent'; a description resonating with processes of otherization tangibly experienced by many immigrants in Canada (Bannerji 2000). Contemporary immigration policies that mark foreigners as 'alien in character' must be examined within the history of racist immigration policies that targeted and excluded Chinese, Japanese, South Asians and Indigenous populations from full participation in Canadian society. As DeGenova (2010) argues, constructions of the foreigner are particularly salient in a discussion of social rights, where nationalism (and periodic waves of xenophobia) is entangled in the social contract to protect citizens. Practices that identify those 'differing in nature or character' serve to distinguish those unworthy of inclusion and thus risky to the nation. 
An evaluative accent (Bakhtin 1981) appears commonly in legislation that characterizes immigrants with precarious status as criminals and threats to security. The Government of Canada states concern regarding the 'health, safety and security of Canadians' as delineated by Citizenship and Immigration Canada (2010b), reifies this commitment through discourses of securitization. Accordingly the IRPA is replete with constructions of foreign nationals as criminal or prone to criminal activity ${ }^{\mathrm{i}}$. In fact, the word criminal (crime, crimes and criminality) appears 73 times in the Act. It is therefore not astonishing that the foreign national is constructed to be an immoral subject. In the IRPA:

(A) person who makes an application must answer truthfully all questions put to them for the purpose of the examination and must produce a visa and all relevant evidence and documents that the officer reasonably requires... A permanent resident or a foreign national is inadmissible for misrepresentation (a) for directly or indirectly misrepresenting or withholding material facts relating to a relevant matter that induces or could induce an error in the administration of this Act... (Government of Canada 2001, emphasis added).

The passage above implies that foreign nationals ought not to be trusted to provide veritable accounts; calling into question their ethics and morality. That being said, the legislation fails to acknowledge the reasons why an individual might be compelled to withhold information; reasons which might prompt their detainment and/or deportation, indeed their very survival. The state's role in creating the vulnerabilities experienced by an immigrant with precarious status is not questioned, while the morality of the immigrant is.

Section 34(2) of the IRPA does allow decisions of inadmissibility to be waived in cases in which the foreign national 'satisfies the Minister that their presence in Canada would not be detrimental to the national interest' (Government of Canada 2001, Sect 34(2) emphasis added). 
It remains unclear how one would satisfy the Minister 'that their presence in Canada would not be detrimental to the national interest' when the Act has already judged that this population by virtue of the status 'foreign' (recall the definition: 'alien in character' referring to one 'differing in nature or character typically to the point of incompatibility' (Merriam-Webster 2010) is criminal.

At the provincial level, the lexical choice to signify precarious status in Ontario's Education Act is one 'unlawfully in Canada':

A person who is otherwise entitled to be admitted to a school and who is less than eighteen years of age shall not be refused admission because the person or the person's parent or guardian is unlawfully in Canada (Government of Ontario 1990a, emphasis added).

While extending the social right of education to all students at the pre-school, primary and secondary levels, the Act is unequivocal that those without legal immigration status are to be considered 'unlawful'. Merriam-Webster (2010) defines unlawful as: 'not lawful; illegal; not morally right or conventional' (emphasis added). In provincial legislation, the use of $\boldsymbol{u n l a w f u l}$ refers to the constraints placed on this piece of legislation, in accordance with other provincial laws and/or federal laws. The provincial legislation cited above notably defers to federal definitions of inclusion. Accordingly, references to immigrants as 'illegal' or 'not morally right' reflect the negotiated boundaries of worthiness and belonging constructed in federal law and maintained through provincial law.

The City of Toronto is the only level of government that explicitly addresses the vulnerabilities faced by immigrants with precarious status. In their Vision Statement on Access, Equity and Diversity, 'The City recognizes the barriers of discrimination and disadvantage faced 
by human rights protected groups' (City of Toronto 2003). Of the three levels of government, the City of Toronto is the only government to rhetorically include all residents in its territory regardless of immigration status. The City assumes no responsibilities with regard to the management of immigrants — a federal responsibility—nor does it fund settlement services for immigrants which is handled by the provincial government and to which many immigrants with precarious status are excluded. The City does, however, assert a responsibility in ensuring that all residents can participate fully in civic life. While the City of Toronto omits language that marks some immigrants as 'illegal' or 'unlawful', the limited scope of the City's responsibility to extend public resources—which more decisively defines membership—weakens the material effects of its inclusive rhetoric.

\section{The right to education via market citizenship}

Now we examine how lexical choices are incorporated into policy and programs related to public education. Elementary, secondary and post-secondary education in Canada falls under the legislative purview of the provinces and territories. As in other policy documents, however, legislation produced by the various levels of governance oft have disparate, conflicting approaches to defining the right to education for immigrants with precarious status. The IRPA of 2001 specifies that the social right of education is extended only to children of foreign nationals who are authorized to work or study in Canada. In contradistinction, the Ontario Education Act mandates compulsory education for all children from kindergarten to grade 12 , irrespective of immigration status (Education Act, R.S.O. 1990, c. E.2). In the City of Toronto, additional steps have been introduced through the Toronto District School Board to ensure access to education including children without status (Toronto District School Board 2007). 
In 2006, Toronto District Schools entered the national media following two high profile cases where non-status children were removed from school by immigration enforcement officers, in an attempt to locate their parents to issue a deportation order. A grassroots campaign led by community organizers with No One Is Illegal took action and pressured the Toronto District School Board to officially adopted a 'Don't ask don't tell' policy within a year. This policy does not require parents to disclose their immigration status and offers alternative ways to verify residence and the child's identity, without having to share personal documents. The Toronto District School Board is still in the process of fully implementing this policy, with a new poster campaign in 2010 which states that "All children living in our community, including those without immigration status in Canada, are entitled to admission in our schools" (No One Is Illegal-Toronto 2010).

Yet, while the City of Toronto supports access to education for all children and the province of Ontario unequivocally mandates both the right to education and responsibility—on the part of parents - to enroll their children, a study by Sidhu (2008) suggests that there are inconsistencies regarding the enforcement of these legal requirements. Out of seventeen respondents in Sidhu's (2008) study, four had been denied enrolment in the TDSB due to their immigration status, and almost all (15 of 17 respondents) stated that their immigration status was raised in the enrolment process (i.e. proof of status requests). More than half of the respondents were unaware that their children had a right to education and many expressed that they were fearful of enrolling their children in school for fear of being deported; not astonishing given the numerous cases of deportation after one's status is exposed (Koehl 2007).

While enrolment forms for Toronto public schools no longer specifically ask for immigration status, applicants are required to indicate their date of entry in Canada (with 
supporting documentation) in order to assess funding for English as a Second Language programs and to ascertain whether international fees are applicable (Sidhu 2008). Similarly, Decter (2007) finds that all schools maintain procedures allowing parents to opt out of fees for trips and activities; these procedures, however, require the disclosure of the family's immigration status. The demand for documentation which exposes immigration status thus nullifies the 'Don't ask don't tell' policy (Koehl 2007). Consequently, the social right to education for children with precarious status in Toronto operates in tension with both city and provincial strategies to generate revenue through 'international' student fees.

The levying of International student fees represents a significant funding strategy for both the provincial and municipal governments. The Toronto District School Board policy initiative for 2009-2010 explicitly identified the recruitment of international students as one of their four strategies to ensure financial stability. This initiative aimed to increase enrollment of international students by $150 \%$ in 2009 , with an anticipated $\$ 2$ million in tuition revenue. Likewise, in the Throne Speech of March 8, 2010 Premier Dalton McGuinty announced Ontario's plan to increase admittance of international students in post-secondary education with international student fees imposed (Benzie 2010). Both policy initiatives signal that foreigners estimated worth to participate in public schools is, in part, determined by their ability to contribute sufficient assets to the community. As schools rely more and more on international student fees to supplement budgetary constraints, values of market citizenship reflect the premise that 'foreign' students are worthy of education, only if they can pay their way.

\section{Safety and protection from harm, except when 'required by law'}

This section unearths the rifts in governmental approaches to 'equal treatment' legislated in human rights law (as a precursor to social rights claims) in relation to citizenship status; 
followed by a discussion of how safety and protection of harm for immigrants with precarious status is jeopardized.

According to the Canadian Human Rights Act, ...All individuals should have an opportunity equal with other individuals to make for themselves the lives that they are able and wish to have and to have their needs accommodated, consistent with their duties and obligations as members of society (Department of Justice Canada 1985, Chap H-6(2), emphasis added).

In defending equal opportunity for individuals, the federal law dilutes the potency of this protection —whilst individuals should have equal opportunity, in effect, they may not. The wording 'should have an opportunity equal with other individuals to make for themselves the lives that they are able and wish to have', lifts the onus off the state to ensure equal opportunity and places it instead on the individual. Equality of opportunity is therefore dependent on individuals' observing their duties and obligations as members of society-indicating that the protection of human rights in Canada relies entirely on individuals meeting their responsibilities, and not at all buttressed by rights ascribed to members of society.

Unlike the Canadian Human Rights Code, the Human Rights Code of Ontario includes citizenship as grounds for equal treatment without discrimination.

Every person has a right to equal treatment with respect to services, goods and facilities, without discrimination because of race, ancestry, place of origin, colour, ethnic origin, citizenship, creed, sex, sexual orientation, age, marital status, family status, and disability... Stores, restaurants, bars, services and programs provided by municipal and provincial governments including social assistance and benefits and public transit (Government of Ontario 1990b, Part I(1), emphasis added). 
If the above statement is indeed true, ought not social assistance and (municipal and provincial) programs and services be extended to those with precarious status, if every person has this right? Regrettably, a caveat delineates that:

A right under Part I to non-discrimination because of citizenship is not infringed where Canadian citizenship is a requirement, qualification or consideration imposed or authorized by law (Government of Ontario 1990b, Sect 16(1)).

This exception clause diminishes individuals' protection from discrimination on the basis of citizenship.

You cannot be discriminated against because of your citizenship except where Canadian citizenship is a legal requirement to get a job or obtain certain services (Ontario Human Rights Commission 2009, p. 32 emphasis added).

Hence, the claim to equal treatment without discrimination is curtailed; valid only if not in conflict with federal requirements implicating one's citizenship as an impediment to garnering benefits and services.

At the municipal level, the interplay between municipal constructions of rights run in conflict with federal and provincial policies. According to posters and guides issued by the City of Toronto, 'The City of Toronto provides services to residents regardless of immigration status'. Furthermore;

Municipal employees must protect the confidentiality of the information belonging to residents who are seeking City services that they are entitled to receive. A person's immigration status is confidential information (emphasis in original). When you apply for or use City services, Toronto employees will not ask about immigration status unless it is required by law. Your status will not be reported to anyone, except when required by law (city of Toronto 2010, emphasis added). 
The City of Toronto indicates that immigration status is confidential information and municipal employees must protect the confidentiality of residents, whilst inserting the words 'unless' and 'except', thereby diluting this commitment. The authoritative wording 'except when required by law' - as noted before - indicates that discretionary power is ultimately constrained by provincial and/or federal law. Thus, when Mayor David Miller indicated that the City of Toronto's programs/services would adopt a 'Don't ask don't tell' policy, his statement only applied to programs and services that are not subject to provincial and federal eligibility criteria and thus require municipal-provincial or municipal-federal information sharing. Thus deference to exceptions carved out by provincial and federal governments are upheld, at the expense of inclusion at the municipal level.

Police cooperation with the Canada Border Service Agency represents a contested site where municipal efforts to provide safety and protection from harm to residents of the cityregardless of status - conflict with interpretations of Canadian law. Although the Toronto Police Board endorsed a proposal to adopt a 'Don't ask don't tell' policy in 2006 and issued that police would only ask about immigration status if there were bona fide reasons to do so, this proposal was later dropped in 2008 (No One Is Illegal 2008). Despite community mobilization to encourage the police to ensure 'access without fear' (Nyers et al. 2006), in November of 2008 Police Chief Bill Blair refused to comply with the 'don't tell' portion of the proposed policy, asserting that, 'We [police officers] have to act both morally and within the rule of law. We've gone I think as far as we can within Canadian law. I can't and I won't issue an unlawful order. In fact you may be asking me to break the law' (Hanes 2008). Whilst not 'necessary' information, the provision 'bona fide reasons' is subject to the individual police officer's judgment. One's 'illegal' (sic) standing in Canada may be sufficient reason to demand identity verification and 
documentation. Clearly the existing tension between the right to safety for immigrants with precarious status and the criminalization of this population is manifest when 'illegal' migrants are in need of protection but poised as subjects of securitization.

\section{Inadmissible due to failed market citizenship: Access and use of social assistance}

The redistribution of resources via income assistance programs (e.g. pensions, employment insurance, child benefits, and social assistance), while representing one of the primary safeguards of social democracy from the vagaries of the market, is also a site where worthiness for social membership is stringently managed. In their international comparison of social rights and citizenship, Fix and Laglagaron (2002) outline the range of social welfare programs offered in Canada, which are primarily funded by the federal and provincial governments. In line with devolutionary shifts, most programs - with the exception of Old Age Insurance and other pension programs, Employment Insurance and Child Tax Benefit programs - are administered at the provincial and municipal levels. Most forms of income assistance (social assistance, child tax benefits, housing assistance), social insurance (medical benefits, pensions, employment insurance) and social investments (immigrant settlement programs, educational grants/loans and job training) are limited to Canadian nationals, legal permanent residents, and officially recognized refugees. Legal-permanent residents who enter in the family class are constrained from social and housing assistance programs as their sponsors must assume financial responsibility for their welfare. Refugee claimants who are in financial need can apply for cash assistance, rent subsidy or social housing. Refugee claimants are also eligible for provincial health insurance and may apply for social assistance and subsidized housing. Use of these programs, however, is scrutinized in immigration/citizenship 
determinations. Temporary foreign workers, while not eligible for any social or housing assistance programs, may be eligible for provincial health insurance, and are (in theory) eligible for Employment Insurance. Non-status immigrants, temporary visitors, and international students are ineligible for provincially and federally funded programs. Community Health Centres which are provincially funded, however, do have some funds set aside for uninsured patients. The City of Toronto also provides a modicum of support in the form of emergency shelters and drop-in services for the homeless.

We analyze how the use of income assistance (i.e. social assistance, housing support, childcare benefits) readily disqualifies immigrants with precarious status from legal permanent residency or citizenship on the basis of their failure to demonstrate independence and autonomy; key ideals of market citizenship. Marshall's (1992) analysis of social citizenship highlighted the 'roles and responsibilities' of citizens who must contribute through their 'labour' in order to achieve the status of citizenship. The consequence of failed market citizenship is further pronounced for immigrants with precarious status who are not only excluded from the social contract, but also subject to deportation. Immigrants with precarious status who pursue access to social rights may jeopardize their admittance to formal citizenship for themselves and other family members. Thus, while being rendered 'inadmissible' for social and health services obviates access to basic needs, it also increases the risk of deportability.

Much attention in Canadian immigration law is given to 'inadmissible' subjects, with the terms 'inadmissible' or 'inadmissibility' occurring 65 times in the Immigration and Refugee Protection Act. Immigration therefore is a one-sided relationship, established on what Canada will gain economically from newcomers, not what it may have to provide for them. 
A foreign national is inadmissible for financial reasons if they are or will be unable or unwilling to support themselves or any other person who is dependent on them, and have not satisfied an officer that adequate arrangements for care and support, other than those that involve social assistance, have been made (Government of Canada 2001, p. 23, emphasis added).

The provision that foreign nationals are inadmissible if they do not satisfy an officer that they will provide 'adequate arrangements for care and support, other than those that involve income assistance programs', resolutely conveys that foreign nationals must not place undue burden on society by accessing the social rights, programs and services reserved for citizens and 'worthier' (permanent) residents. The inadmissibility of foreign nationals from the social right of income assistance is thus fixed to their inability or unwillingness 'to support themselves or any other person who is dependent on them'.

Verification certifying identity claims is central in the determination of eligibility for a range of social services including income assistance programs. Ontario's social assistance program for financial and employment support, Ontario Works, requires, 'proof of your Social Insurance Number, Health Card, proof of identity, such as your birth certificate... and proof of immigration status, if required...' (Ministry of Community and Social Services 2009b, emphasis added). Similarly, for the Ontario Disability Support Program (ODSP):

You may be asked to give or show your worker certain documents about you and your family...: birth certificates, immigration papers, Social Insurance Numbers (SIN), Ontario health card numbers (OHIP), documents about your housing costs, documents about your income, documents about your assets (Ministry of Community and Social Services 2009a, emphasis added).

The demand to produce documents verifying one's identity for such programs is 
largely out of the question for immigrants with precarious status. If an individual were to inquire about their eligibility (given the absence of this information on the webpage), any information procured by provincial administrators could be shared with immigration officials (as per the provincial information sharing agreement with Citizenship and Immigration Canada (City of Toronto 2007), placing the individual/family in danger of detainment and/or deportation.

The perceived dangers of foreign nationals have sanctioned wide-ranging identity verification and surveillance mechanisms designed to capture biologized bodies deemed to be threats to national security. As an emergent mechanism of governmentality, biometrics produces a narrow classification system intended to expose those in/out of favour with the state. Identifying one's racial identity is consequently a priority; intensified in regimes consumed with thwarting the designs of extremist groups and terrorist cells (Birt 2008). Moreover, by vigorously directing the spotlight to criminality and securitization, access to social rights for immigrants, in addition to citizens who are unable to verify their citizenship identity, is actively limited (Crépeau and Nakache 2007).

\section{Discussion}

\section{Few rights, many responsibilities}

In this paper, we analyzed public policy documents at the federal, provincial and municipal level, to illuminate the discourses surrounding the expression of social rights for immigrants with precarious status in Toronto, Ontario. We presented our analysis juxtaposing homo economicus — used to define the good, desirable citizen — with constructions of precarious legal status as criminal and threatening to national security. Associated with citizenship is a wide continuum of rights and obligations, albeit the responsibilities of citizenship have gained 
precedence over and above rights in the contemporary post-welfare state (Orloff 1996, Sainsbury 1996, Lister 2003). Indeed, what these rights are and how they are negotiated is uncertain. While considered one of the mainstays of classical liberalism, the contention of Marshall (Marshall 1981, Marshall 1992) that social rights be added to the array of rights (political and civil) extended to citizens within the state is increasingly at odds with extant neoliberal realities. Muddying the conceptual waters further, the question of who is a citizen and how one realizes greater approximations of full citizenship, is problematic.

Our exploration of how features of citizenship are produced in Toronto, Ontario exposes immense rifts in federal, provincial and municipal policy for immigrants with precarious status vis-à-vis citizens and permanent residents. Multifarious layers of restrictive criteria limit access for immigrants with precarious status from social services due to perceptions of this population as deficient market citizens, presenting dangers to national 'health, safety and security' (Citizenship and Immigration Canada 2010a). As a result, some residents in Canada experience profound vulnerabilities and exclusion, in constant fear of detainment and deportation. Consequently the quandaries associated with citizenship and social rights' claims in Canada are widening and do not appear within reach of resolution anytime soon. What does emerge are myriad tensions and contradictions: between rights and (market citizenship) responsibilities; between the various levels of governance in the articulation and interpretation of social rights; between the valued economic contribution of immigrants, also postulated to be criminal and threats to national security.

Through a closer look at how subnational territories are defining membership and conferring rights within their territorial boundaries, our analysis contributes to the ongoing theorization of postnational forms of citizenship, with attention to people who are excluded from 
juridical citizenship. While postnational forms of citizenship may be possible for some, we argue that neoliberal values of citizenship — or market citizenship — continue to exclude populations from mobilizing rights, either from within the nation-state or from supra-national human rights regimes. Furthermore, rights and membership for people with precarious status are directly constrained by constructions of illegality/unlawfulness, questionable morality, and criminalityframes which fittingly align with the national interests in securitization. While our analysis of public policy documents illustrates how rights and membership are defined by different levels of government, additional research is needed to examine the negotiated realm of membership, identity and rights by migrants and other state and nongovernmental actors (Basok 2004).

In the case of Toronto, the willingness of municipal administrators to extend social rights - unattached to federal/provincial eligibility requirements - indicates there is room for negotiation and movement. Although Toronto has not fulfilled the potential of declaring itself a 'sanctuary city', in the likeness of some cities south of its border, the municipal government with pressure from grassroots mobilization, has sought to allow all residents of Toronto to access city services (McDonald 2007). The downloading of provincial and federal programs, with their prescribed eligibility and funding criteria, however, stymies the City's gesture of inclusion. funding) however, constrains the City's gestures of inclusion. As long as the city relies on federal and provincial funds to deliver services to residents (including those with precarious status), its definitions of membership and belonging will continued to be devalued. At the same time endeavoring to maintain the appearance of inclusiveness, the City continues to defer to provincial and federal authority. Consequently, hundreds of thousands of residents in Toronto lack the basic minimum standards that are rhetorically upheld in Canadian or international human rights laws. 
Scholarship on citizenship must take into account the growing number of non-status inhabitants (Bosniak 2006), a population representing a veritable explosion of people who reside within the nation-state but are systematically excluded from the benefits ascribed the citizenry. Our analysis centres on postnational citizenship as a promising frame from which to understand the shifting migration flow and the policies attached to migrants, specifically those who may not have the documentation to certify their legal right to reside in Canada. To return to the question, where can citizenship take place? We argue that sub-national levels of governance (i.e. the City of Toronto) appear to have the willingness to adopt inclusivity (at least rhetorically) as its ideal for all residents within its boundaries. The City's commitment to recognize all residents, including those with precarious immigration status, with the potential to afford resources in their favour, permits but a small crack in the foundation of nationally defined citizenship. Purcell (2003) discusses in this vein how citizenship is being: 1) rescaled - the hegemony of the nationalscale political community is being weakened by the formation of communities at other scales; 2) reterritorialized - the link between the nation-state's territorial sovereignty and citizens' political loyalties are being challenged; and 3) reoriented - away from the nation as the predominant political community. Over time, these forces may propel national and provincial levels of government to alter their rigid definitions of membership and belonging in favour of a more inclusive vision. Today however the City of Toronto's rhetoric of inclusivity remains unfulfilled. 


\section{References}

Anonymous, 2006. Through the back door. Canada and the World Backgrounder, 72, 17-21.

Bakhtin, M.M., 1981. Discourse in the novel. In M. Holquist (ed.) The dialogic imagination:

Four essays by M.M. Bakhtin. Austin: University of Texas Press, 259-242.

Bannerji, H., 2000. Dark side of the nation: Essays on multiculturalism, nationalism and gender. Toronto: Canadian Scholar's Press.

Basok, T., 2004. Post-national citizenship, social exclusion and migrants rights: Mexican seasonal workers in Canada. Citizenship Studies, 8, 47-64.

Benhabib, S., 2004. The rights of others: Aliens, residents and citizens. Cambridge: Cambridge University Press.

Benzie, R., 2010. Ontario wants more foreign students. The Star. Toronto.

Bosniak, L., 2000. Citizenship denationalized. Indiana Journal of Global Legal Studies, 7, 447510.

Bosniak, L., 2006. The citizen and the alien. Princeton: Princeton University Press.

Boushey, G. and Luedtke, A., 2006. Fiscal federalsim and the politics of immigration: Centralized and decentralized immigration policies in Canada and the United States. Journal of Comparative Policy Analysis, 8, 207-224.

Calavita, K., 2005. Immigrants at the margins: Law, race, and exclusion in Southern Europe. Cambridge: Cambridge University Press.

Caldas-Coulthard, C.R., 2003. Cross-cultural representation of otherness in media discourse. In G. Weiss and R. Wodak (eds.) Critical discourse analysis: Theory and interdisciplinarity. New York: Palgrave Macmillan, 272-296. 
Cameron, D. and Simeon, R., 2002. Intergovernmental relations in Canada: The emergence of collaborative federalism. Publius: The Journal of Federalism, 32, 49-71.

Chan, W., 2005. Crime, deportation and the regulation of immigrants in Canada. Crime, Law \& Social Change, 44, 153-180.

Citizenship and Immigration Canada, 2009. Facts and figures 2009: Immigration overview-permanent and temporary residents. Ottawa.

Citizenship and Immigration Canada, 2010a. Biometrics [online]. http://www.cic.gc.ca/english/department/biometrics.asp7, July 2010].

Citizenship and Immigration Canada, 2010b. Who we are [online]. http://www.cic.gc.ca/english/department/mission.asp 7 July, 2010].

City of Toronto, 2003. Vision statement on access, equity and diversity [online]. [Accessed 16 June, 2010].

City of Toronto, 2007. Access to services for Toronto residents. Information and identification requirements [online]. http://www.toronto.ca/immigration/pdfs/information/dadt_services.7 July, 2010].

City of Toronto, 2010. The City of Toronto provides services to residents regardless of immigration status. City of Toronto.

Cowen, D., 2005. Suburban citizenship? The rise of targeting and the eclipse of social rights in Toronto. Social \& Cultural Geography, 6, 335-356.

Crépeau, F. and Nakache, D., 2007. Controlling irregular migration in Canada: Reconciling security concerns with human rights protections. Choices: Immigration and Refugee Policy, 12. 
De Genova, N., 2005. Working the boundaries: Race, space and "illegality". Mexican Chicago.

Durham, NC: Duke University Press.

De Genova, N. (ed.) (2010) The deportation regime: Sovereignty, space, and the freedom of movement, : Duke University Press.

Decker, S.H., Lewis, P.G., Provine, D.M. and Varsanyi, M.W., 2008. Immigration and local policing: Results from a national survey of law enforcement executives [online]. Arizona State University. Available from: http://chsdev.asu.edu/docs/ccj/ccji/Immigration_and_Local_Policing.pdf

Decter, A., 2007. Lost in the shuffle: The impact of homelessness on children's education in Toronto. Community Social Planning Council of Toronto. Kids Builders Research Project.

Department of Justice Canada, 1985. Canadian human rights act. Government of Canada.

Dhamoon, R. and Abu-Laban, Y., 2009. Dangerous (internal) foreigners and nation-building: The case of Canada. International Political Science Review, 30, 163-183.

Dobrowolsky, A., 2008. Interrogating 'invisibilization' and 'instrumentalization': Women and current citizenship trends in Canada. Citizenship Studies, 12, 465-479.

Epsing-Andersen, G. (ed.) (1996) Welfare state in transition: National adaptations in global economies, London: Sage Publications.

Fix, M. and Laglagaron, 2002. Social rights and citizenship: An international comparison. Washington, D.C.

Fix, M. and Tumlin, K., 1997. Welfare reform and the devolution of immigrant policies. Washington, D.C. 
Fonow, M.M. and Cook, J.A., 2005. Feminist methodology: new applicaitons in the academy and public policy. Signs: Journal of Women in Culture and Society, 30, 2211-2286.

Gadamer, H.-G., 1979. Philosophical hermeneutics. Berkeley: University of California Press.

Gilbert, E., 2007. Leaky borders and solid citizens: Governing security, prosperity and quality of life in North American partnership. Antipode, 39, 77-98.

Glatzer, M. and Rueschemeyer, D. (eds.) (2005) Globalization and the future of the welfare state, Pittsburgh: University of Pittssburgh Press.

Goldring, L., Bernstein, C. and Bernhard, J., 2010. Institutionalizing precarious migratory status in Canada. Citizenship Studies, 13, 239-265.

Government of Canada, 2001. Immigration and Refugee Protection Act.

Government of Ontario, 1990a. Education Act.

Government of Ontario, 1990b. Ontario Human Rights Code.

Graham, J.R., Swift, K.J. and Delaney, R., 2009. Canadian social policy: An introduction. Toronto: Pearson Prentice Hall.

Hanes, A. 2008. Police chief kills "don't tell" immigration policy National Post November 20.

Hewitt, P., 1996. Social justice in a global economy? In M. Bulmer and A.M. Rees (eds.) Citizenship today: The contemporary relevance of T.H. Marshall. London: Routledge, 249-268.

Koehl, A., 2007. Unlocking the school door: Immigration status and the right to learn. Education Canada, 47, 58-61.

Lister, R., 2003. Citizenship: Feminist perspectives. New York: New York University Press.

Marshall, T.H., 1981. The right to welfare and other essays. London: Heinemann. 
Marshall, T.H., 1992. Citizenship and social class. In T.H. Marshall and T. Bottomore (eds.) Citizenship and Social Class. London and Concord: Plut Press.

Mcbride, S. and Mcnutt, K., 2007. Devolution and neoliberalism in the Canadian welfare state: Ideology, national and international conditioning frameworks, and policy change in British Columbia. Global Social Policy, 7, 177-201.

Mcdonald, J., 2007. Citizenship, illegality, and sanctuary. In V. Angew (ed.) Interrogating race and racism. Toronto: University of Toronto Press, 112-134.

Merriam-Webster, 2010. Dictionary.

Midgley, J., 2007. Perspectives on globalization, social justice and welfare. Journal of Sociology \& Social Welfare, XXXIV, 17-36.

Ministry of Community and Social Services, 2009a. Ontario disability support program financial eligibility. Government of Ontario.

Ministry of Community and Social Services, 2009b. Ontario Works. How to apply for Ontario Works. Government of Ontario.

Mishra, R., 1999. Globalization and the welfare state. Cheltenham, UK: Edward Elgar.

Morris, J., 1997. Neo-liberal strategies to cut cotsts in settlement services: Cost recovery and devolution. Refuge, 15, 25-26.

Munger, F., 2003. Poverty, welfare, and the affirmative state. Law and Society Review, 37, 659686.

No One Is Illegal-Toronto, 2010. Toronto schools a little more welcoming for undocumented students.

No One Is Illegal, 2008. Implement DADT at the Toronto Police Board [online]. NOII Toronto. Available from: http://toronto.nooneisillegal.org/node/253July 12, 2010]. 
Nyers, P., 2005. The regularization of non-status immigrants in Canada: Limits and prospects. Canadian Review of Social Policy, 55, 109-115.

Nyers, P., Zerehi, S.S. and Wright, C., 2006. 'Access not fear': Non-status immigrants and city services. Toronto.

Ong, A., 1999. Flexible Citizenship: The cultural logics of transnationality. Durham \& London: Duke University Press.

Ong, A., 2006. Mutations in citizenship. Theory, Culture \& Society, 23, 499-531.

Ontario Human Rights Commission, 2009. Guide to your rights and responsibilities under the Human Rights Code. Government of Ontario.

Orloff, A.S., 1996. Gender in the welfare state. Annual Review of Sociology, 22, 51-78.

Porter, B., 2005. Social and eocnomic rights and the Canadian Charter of Rights and Freedoms. International conference on social and economic rights: Models of enforcement. Dublin, Ireland: Irish Human Rights Commission.

Purcell, M., 2003. Citizenship and the right to the global city: Reimagining the capitalist world order. International Journal of Urban and Regional Research, 27, 564-590.

Sainsbury, D., 1996. Gender, equality and the welfare state. Cambridge: Cambridge University Press.

Sassen, S., 2001. The global city: New York, London, Tokyo. Princeton: Princeton University Press.

Sassen, S., 2003. The repositioning of citizenship: Emergent subjects and spaces for politics. The New Centennial Review, 3, 41-66.

Schild, V., 2000. Neo-liberalism's new market citizens: The civilizing dimension of social programs in Chile. Citizenship Studies, 4, 275-305. 
Schmidtke, O., 2008. Introduction: National closure and beyond. In O. Schmidtke and S. Ozcurumez (eds.) Of states, rights, and social closure. New York: Palgrave MacMillan, $1-14$.

Shantz, J.A., 2005. No one is illegal: Organizing beyond left nationalism in Fortress North America. Socialism and Democracy, 19, 179-185.

Sidhu, N., 2008. The right to learn: Access to public education for non-status immigrants [online]. Community Social Planning Council of Toronto. Available from: http://socialplanningtoronto.org/wp-content/uploads/2009/02/right to_learn.pdf [Accessed 7 July, 2010].

Spiro, P.J., 2001. Federalism and immigration : models and trends. International Social Science Journal, 53, 67-73.

Statistics Canada, 2009. 2006 Census: Immigration in Canada: A portrait of the foreign-born population, 2006 Census: Highlights [online]. http://www12.statcan.ca/censusrecensement/2006/as-sa/97-557/p1-eng.cfm [Accessed 7 July, 2010].

Toronto District School Board, 2007. Program and School Services Committee Report No. 3 [online]. http://www.tdsb.on.ca/ [Accessed 7 July, 2010].

Van Dijk, T.A., 1993. Principles of critical discourse analysis. Discourse and Society, 4, 249283.

Varsanyi, M.W., 2006. Interrogating "urban citizenship" vis-à-vis undocumented migrants. Citizenship Studies, 10, 229-249.

Varsanyi, M.W., 2008. Immigration policing through the backdoor: City ordinances, the "right to the City," and the exclusion of undocumented day laborers. Urban Geography, 29, 29-52. Yanow, D., 2000. Conducting interpretive policy analysis. Thousand Oaks: Sage Publications 
Constructions of Migrant Rights 


\section{Figure 1}

Visual depiction of social rights' domains and analytic frames explored in the study.

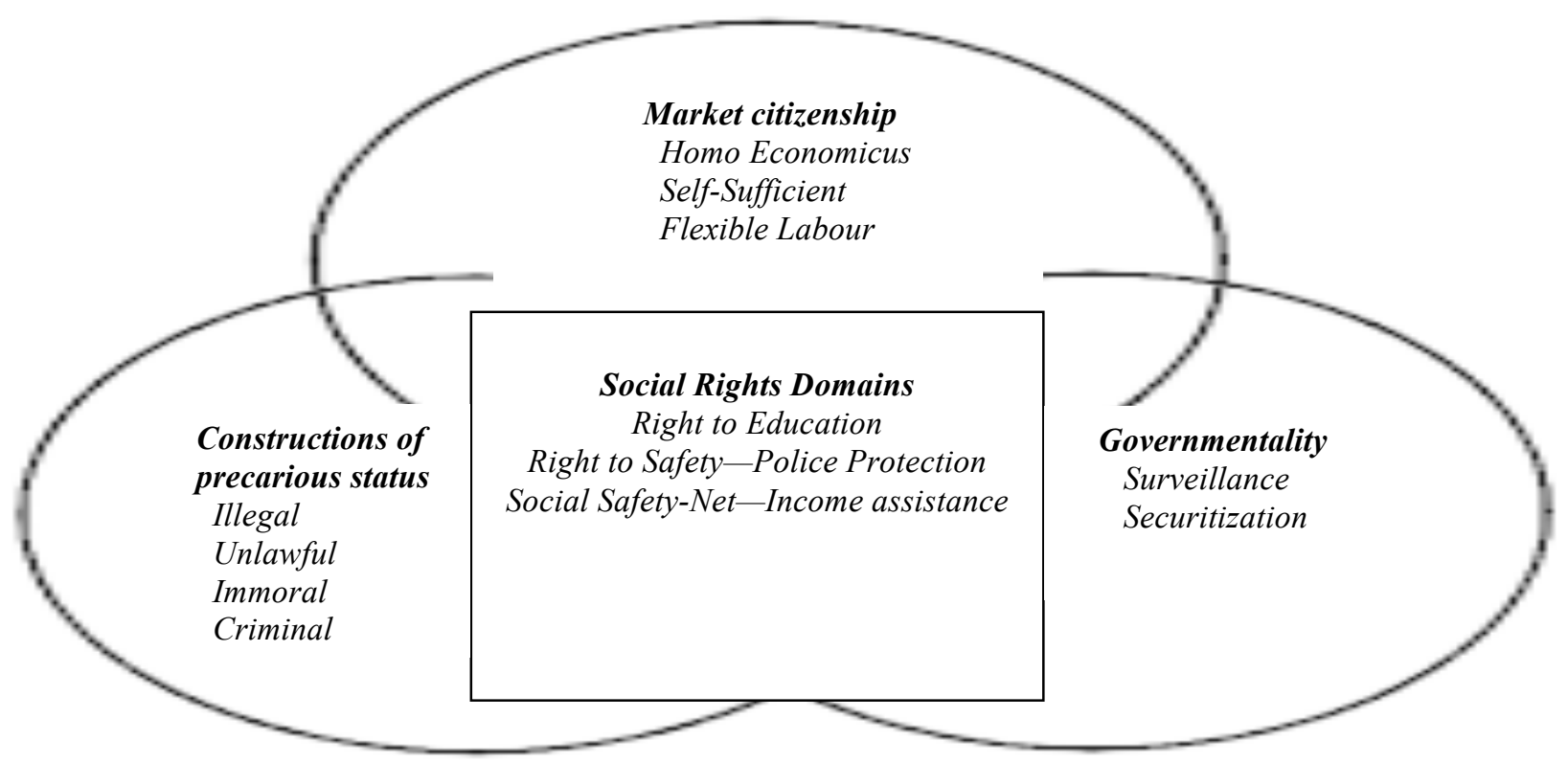


Table 1: Policy Documents by Level of Government

\begin{tabular}{|c|c|}
\hline Policy Document(s) & $\begin{array}{c}\text { Level of } \\
\text { Government }\end{array}$ \\
\hline \multicolumn{2}{|l|}{ Immigration/Immigrant Policy } \\
\hline Citizenship and Immigration Canada Webpage & Federal \\
\hline Immigration and Refugee Protection Act & Federal \\
\hline Settlement Services policy & Federal \\
\hline \multicolumn{2}{|l|}{ Human Rights Policy } \\
\hline Canadian Charter of Rights and Freedoms & Federal \\
\hline Ontario Human Rights Act & Provincial \\
\hline City of Toronto Declaration of Non-Discrimination & Municipal \\
\hline \multicolumn{2}{|l|}{ Welfare Policy } \\
\hline Old Age Security/ Guaranteed Income Supplement policies & Federal \\
\hline Social Housing Reform Act & Provincial \\
\hline Canada Child Tax Benefit & Federal \\
\hline Ontario Works/ Ontario Disability Support Program & Provincial \\
\hline City of Toronto Childcare Policy & Municipal \\
\hline City of Toronto Access to Programs \& Services guide & Municipal \\
\hline \multicolumn{2}{|l|}{ Education } \\
\hline Ontario Education Act & Provincial \\
\hline Toronto District School Board Website & Municipal \\
\hline \multicolumn{2}{|l|}{ Police Protection } \\
\hline Toronto Police Service Website & Municipal \\
\hline
\end{tabular}

* Note-In this paper we focus on education, income assistance, and police protection; thus not all policies were included in the analysis section of this paper. 
A permanent resident or a foreign national is inadmissible on security grounds for

(a) Engaging in an act of espionage or an act of subversion against a democratic government, institution or process as they are understood in Canada;

(b) Engaging in or instigating the subversion by force of any government;

(c) Engaging in terrorism

(d) Being a danger to the security of Canada

(e) Engaging in acts of violence that would or might endanger the lives or safety of persons in Canada

(f) Being a member of an organization that there are reasonable grounds to believe engages, has engaged or will engage in acts referred to in paragraph (a), (b), or (c) (Department of Justice 2001). 